\title{
THE EFFECT OF LEISURE ACTIVITIES ON LIFE SATISFACTION: The Importance of Holiday Trips
}

Jeroen Nawijn ${ }^{1}$ and Ruut Veenhoven ${ }^{2}$

\author{
I. Brdar(ed.), The Human Pursuit of Well-Being: A Cultural Approach. \\ Springer Science, 2011, pp 39-53, ISBN 978-94-007-1374-1. \\ DOI 10.1007/978-94-007-1375-8 4.
}

In recent years, the phenomenon of happiness has been receiving increased interest. People want to know what can possibly make them happier. Generally speaking, there are two ways to improve happiness, one is to change one's view on life and the other is to change one's way of life. The latter way is promising since approximately $40 \%$ of variance in happiness is attributable to intentional activity (Lyubomirksy. Sheldon. \& Schkade. 2005). Still, there is a lack of knowledge of what ways of life are the most satisfying and, in particular, about the happiness revenues of different leisure activities.

\section{RESEARCH INTO HAPPINESS AND LEISURE}

Happiness researchers are quite knowledgeable on the subject of work but less so on leisure. The World Database of Happiness currently lists 585 correlations between work and happiness and only 91 correlations between leisure activities and happiness (Veenhoven, 2008). Thus, the effect of work on happiness is a well-explored area of research, but far less is known about how participating in leisure activities affects happiness. Work, leisure, and happiness are interrelated (Haworth. 1997). For example, the number of working hours has a strong negative effect on leisure satisfaction, whereas the effect of the number of hours spent on leisure has only a small positive effect on leisure satisfaction (Van Praag, Frijters, \& Ferrer-i-Carbonell, 2003).

\subsection{Happiness and Leisure Satisfaction}

The subjective evaluation of different aspects of life is known to correlate fairly strongly with life satisfaction (Ateca-Amestoy, Serrano-del-Rosal, \& Vera-Toscano, 2008; Lloyd \& Auld, 2002; Van Praag \& Ferrer-i-Carbonell, 2004: Van Praag et al, 2003). Evaluations of finance, health, and job satisfaction, together with leisure satisfaction are the four most important correlates (Van Praag et al., 2003). Ateca-Amestoy et al. (2008) and Spiers and Walker (2009) find positive associations between leisure satisfaction and life satisfaction. Neal et al. (1999) constructed a model based on the assumption that "life satisfaction is functionally related to satisfaction with all of life's domains and subdomains" (Neal, Sirgy, \& Uysal, 1999, p. 154). In 2004. Neal and Sirgy (2004) further validated this model by demonstrating that there is a correlation between satisfaction with leisure life and satisfaction with life in general. A similar model was developed by Sirgy, Rahtz, Cicic, and Underwood (2000). whose model includes

${ }^{1}$ J. Nawijn

NHTV Breda University of Applied Sciences \& Faculty of Social Sciences. Erasmus University. Rotterdam. The Netherlands e-mail: nawijn@,fsw.eur.nl

2 R. Veenhoven

Faculty of Social Sciences. Erasmus University. Rotterdam, The Netherlands e-mailveenhoven@fsw.eur.nl

Acknowledgments The authors thank associate professor Paul Peelers and Nina Delbressine for their valuable comments and help 
leisure as part of the "global satisfaction with other life domains" (Sirgy \& Comwell. 2001: Sirgy et al., 2000).

\subsection{Happiness and Leisure Activities}

Increased satisfaction with leisure and higher frequency of participation in leisure activities positively correlate with life satisfaction (Lloyd \& Auld. 2002). Others also find that participating in leisure activities has a positive correlation with life satisfaction (Baldwin \& Tinsley, 1988; Dowall, Boiler, Flett, \& Kammann, 1988; Wankel \& Berger, 1990). Research efforts to dale tend to focus on the total frequency of a group of leisure activities on either happiness or leisure satisfaction. However, not enough attention has been paid to the effect of specific leisure activities on happiness. Whenever a happiness study does address leisure activities, it usually involves one specific leisure activity, such as listening to music (Laukka, 2007) or watching television (Bruni \& Stanca, 2006. 2008; Delle Fave \& Bassi, 2003; Frey, Benesch, \& Strutzer, 2005).

The majority of leisure studies are cross-sectional; therefore, it is difficult to determine cause and effect.

\subsection{Happiness and Tourism}

Specifically addressing the component of holiday trips, several studies have examined its correlation with happiness (Gilbert \& Abdullah. 2002, 2004; Milman, 1998: Neal, 2000; Neal \& Sirgy, 2004; Neal et al., 1999). Milman's study, based on a sample of senior citizens, shows that holiday trippers are not happier after their holiday (Milman, 1998). Nawijn (2007) finds a low. but positive, correlation between holiday trips and happiness. His findings confirm those of Gilbert and Abdullah (2004) and Neal and Sirgy (2004), who conclude that holiday trips positively influence the sense of well-being of tourists. On the other hand, not every study finds only positive consequences of holiday tripping. High job stress, caused by work not being done during the vacation, for instance, is associated with poorer well-being (Strauss-Blasche, Ekmekcioglu, \& Marktl, 2002). Returning to work where one finds more work piled up compared to the prevacation period results in higher levels of stress.

None of the aforementioned studies measured both happiness and tourism over a long period of time. Thus, cause and effect are not always clear.

\subsection{Aim of This Chapter}

In this chapter, we try to disentangle cause and effect in the relationship between happiness and leisure activity and seek an answer to the following questions: What is the effect of leisure activities on happiness? Do holiday trips have a bigger impact than other leisure activities? And finally, does everyone benefit from these activities'?

The purpose of this chapter is to determine the effect of leisure activities on happiness in terms of strength and cause and effect. This study clarifies which leisure activities increase happiness. Over-time correlations were calculated, to be certain that happy people did not participate more in leisure activities in general. Additionally, to further determine the causeeffect relationship, all effects were controlled for by demographic variables and personality.

\section{METHOD}

These questions are answered by means of data of the German Socio-Economic Panel Study (SOEP), which were made available to us by SOEP at the German Institute for Economic Research (DIW Berlin). Four waves of that study involved questions about leisure activities, The longitudinal design allows the separation of cause and effect and rich background variables allow a check for possible spurious correlation. 


\subsection{Data}

SOEP is a large-scale representative panel of private households, which exists since 1984.

Participants arc interviewed once a year. Leisure activities are not automatically included in the questionnaires but were included in the waves of 1990. 1995.

1998, and 2003. The wave of 1990 consists of $\sim 9,500$ West Germans and 4.300 East Germans. The 1995 wave holds $\sim 13,600$ people, the 1998 wave $\sim 14,500$ people, and the 2003 wave $\sim 20,400$. The panel consists of Germans living in the former eastern and western part, foreigners and recent immigrants to Germany. SOEP contains 18 main topics including "health." "education and qualification." "job market and occupation." and "socialization." The topic "Basic orientation, participation, and integration" includes measures of subjective wellbeing.

\subsection{Variables the Following Variables are Used}

\subsubsection{Dependent Variable: Life Satisfaction}

The dependent variable of the present study is life satisfaction, which we define as "the overall appreciation of one's life as a whole." This concept is delineated in more detail in Veenhoven (1984) and is also labeled as "happiness." The focus of this chapter is on present satisfaction with life.

Life satisfaction is measured using a self-report on a single question: "And finally, we would like to ask you about your satisfaction with your life in general. Please answer by using the following scale, in which 0 means totally unhappy, and 10 means totally happy." The exact question was phrased as: "How satisfied are you at present with your life as a whole?" This question is in SOEP's core questionnaire and responses are, therefore, available for all respondents in all years.

\subsubsection{Independent Variable: Leisure Activities}

The 1990 wave of the SOEP study included the following leisure activities: go out to eat or drink, visit neighbors, visit family member, play card and board games, participate in local politics, perform volunteer work, attend church or other religions events, watch television, video, read nonfiction and fiction, engage in artistic and musical activities, perform handicraft and home repairs, participate in sports, attend sports event, attend cinema, pop. jazz concerts and attend cultural events. The East German data did not contain the variable of holiday trips, but included two different activities: attend community events and attend social gatherings. The 1990 data for East Germany contain only a small range of leisure activities (6 out of the 15). which were used in the West German sample. For this reason, the East German data were excluded from analysis. The 1995 wave included the same leisure activities as the 1990 West German wave. The 1998 wave omits play card and board games, engage in artistic and musical activities, perform handicraft and home repairs and read nonfiction and fiction. The 1998 wave contained some new activities, namely, private personal computer use. tinkering and garden work, car repairs and attend opera/classical concerts and theater. The 2003 activities were almost the same as those of 1998, with just one addition: private internet usage. 


\subsection{Holiday Trips}

The focus of this chapter is on "holiday trips," i.e.. day trips and short holidays. This independent variable was part of the SOEP study in 1990 (West Germany). 1995, 1998, and 2003. The wording of the questions and answers slightly varies over the years. In 1990 and 1995. the following phrasing was used: "Now some questions about your free time. How frequently do you undertake the following activities?" Then several items were listed, among which were outings or short trips. This variable contained the following choices: "daily, once a week, once a month, less than once a month, never." In 1995, instead of asking how frequently one participated in the activities, the question was as follows: "Please indicate how often you engage in the following activities: daily, at least once a week, at least once a month, less often or never."' The responses were equal to the ones pointed out in the question itself. The name of the variable had "excursions" added to it: outings, excursions, short trips. Again, in 2003. some minor changes were made. The question was rephrased as: "Please indicate how often you take part in each activity: daily, at least once a week, at least once a month, seldom, or never." with corresponding answers. Finally, the variable was renamed: go on a trip or short holiday.

\subsubsection{Control Variables}

To ensure that correlations between leisure activities and happiness are not driven by a common third variable, personality, health and socio-demographic variables are used as control variables.

\section{Personality}

The "big five" most important personality traits are: extraversion. agreeableness. conscientiousness, neuroticism and openness to experience (McCrae \& John, 1992, p. 175). The SOEP study includes measures of these five dimensions (Dehne \& Schupp, 2007). As personality traits are deemed fairly stable (Costa \& McCrae, 1994; Gustavsson, Weinryb, Goransson, Pedersen, \& Åsberg, 1997; Hampson \& Goldberg, 2006; McCrae \& Costa, 2003; Terraciano, Costa. \& McCrae, 2006), the 2005 measurement is used for each year of analysis.

\section{Health}

Health is measured as the total number of doctor visits in the past 3 months.

\section{Socio-demographic Variables}

Age, sex, marriage, education, work and income are the socio-demographic variables used in this study. Income is defined as the average gross amount of salary.

\subsection{Analytic Approach}

We started with a same-time analysis to see whether happiness and leisure activities arc related. Next, we did an over-time comparison to get an idea about cause and effect.

The same-time analysis was done using Pearson correlations. First, we computed simple zero-order correlations for assessing to what extent happiness goes together with leisure activities. To check whether these same-time correlations are spurious, we also computed partial correlations. Over-time correlations were used to gain an insight into cause and effect and to determine the duration of effects. Again, we computed both zero-order and partial correlations. Missing values were deleted list-wise. Each wave contained $~ 500$ cases with missing values, the final wave $(\mathrm{n}=22.400)$ had more missing values, namely $\sim 2,000$ cases.

\section{RESULTS}

Correlations for each of the four waves are presented in the appendices to this chapter. Table 4.1 presents the average correlation across all four waves. These averages were computed as a weighted mean, whereby the weights were equal to the inverse variance of each wave's effect estimator. 


\subsection{Same-Time Zero-Order Correlations}

Just five leisure activities (LAs) have significant correlations with life satisfaction (LS). The LAs with significant correlations are holiday trips, attending church, handicrafts, home repairs and attending cultural events.

The leisure activity with the largest correlation each year is holiday trips (shown in Appendix 1). The waves of 1990, 1995, 1998 and 2003 have effect sizes of .15 $(p<.01) . .15(p<.01), .18$ $(p<.01)$ and $.19(p<.01)$. respectively. Thus, the effect sizes are rather similar for each wave. On top of that, holiday trips is the only leisure activity which has a significant effect each year. Three of the other activities do not have a significant effect each year, but their mean effects are significant. The leisure activities that have significant mean zero-order correlations are holiday trips, attending church, handicraft, home repairs and attend cultural events.

\subsection{Same-Time Partial Correlations}

When examining the mean partial correlations (shown in Table 4.1, Column 3). it is immediately obvious that, out of the four significant mean zero-order effects, just one remains significant. Beyond any doubt, holiday trips is the most important leisure activity with mean partial effect sizes of .11 $(p<.01), .09(p<.01), .19(p<.01)$ and $.16(p<.01)$. Holiday trips is the only leisure activity that has an independent effect on happiness: all the other mean zero-order correlations are no longer significant after controlling for age. sex. marriage, education, work, income, personality and health. The size of the correlation is small but considerable: holiday trips accounts for $\sim 2 \%$ of the variance in life satisfaction.

\subsection{Over-Time Correlations}

This leaves us with the question of cause and effect: do holiday trips make us happier? Or, does happiness make us take holiday trips? To answer these questions, we did an across-time comparison. Since the SOEP study involves annual interviews, the minimal period we can use is 1 year.

\subsection{Does Life Satisfaction Predict Leisure Activity 1 Year Later?}

Could it be that happiness is the cause, happy people being more open to fun? This does not seem to be the case, as life satisfaction scores do not predict leisure activity scores 1 year later. The correlation is in fact negative, suggesting that it is unhappiness that predisposes people to take a holiday trip (see Column 4 in Table 4.1 and the detail in Appendix 2). No leisure activity has a consistent significant over-time correlation with the preceding life satisfaction score.

\section{Does Leisure Activity Predict Life Satisfaction 1 Year Later?}

Is the same-time correlation due to an effect of holiday trips on happiness? The over-time correlation is positive (.01) but does not reach statistical significance. So if there is an effect of holiday trips on happiness, it is apparently short lived and hardly visible anymore after a year. None of the leisure activities have consistent significant correlations with life satisfaction in the following year (see Column 5 in Table 4.1 and the detail in Appendix 3). 


\section{DISCUSSION}

\subsection{Do Holiday Trips Boost Happiness?}

Probably, but not certainly. People who did a trip a year appear to be somewhat happier in that year, and this applies to all kinds of people: working or not. an extrovert or an introvert, healthy or sick, rich or poor, married or single, and old or young. Still, it is not established that this correlation is due to an effect of holiday trips on happiness or an effect of happiness on holiday taking. None of these effects is reflected in significant correlations after 1 year, but these correlations of earlier trips on later happiness are positive, while the correlation of earlier happiness on later trip tends to the negative.

Suppose that the effect of holiday trips on happiness is the main driver of the same-year correlation. Holiday trips then have a short-lived effect on happiness. Is this effect big enough to be important? The answer to that question should be "yes." A $2 \%$ increase in happiness may not seem like a lot as such, but it is. when compared to other methods to increase happiness (Seligman. Steen, Park. \& Peterson, 2005). Unlike this study, Seligman et al.'s study included people who were eager to improve their happiness. Even so, some of their techniques were less successful. Their positive intervention of gratitude visits had an effect size of .06 after 1 month (Seligman et al.. 2005. p. 417), which is lower than the .14 effect size of holiday trips. Otake, Shimai, Tanaka-Matsumi, Otsui and Fredrickson (2006) conducted a study on counting kindness, among women. Their counting kindness intervention increased happiness by .44 on a seven-point scale (Otake et al., 2006), which is equal to a .06 effect size. much lower than the .14 of holiday trips. Apart from the smaller effect, women are also more attuned to kindness (Baskersville et al., 2000). The "identifying signature strengths" intervention technique (Seligman et al., 2005) has an effect size of .25 at the immediate post-test, which is higher than the effect size of holiday trips, but its effect is short lived as there is only immediate gratification (1 week post-tests were not significantly different from the control group).

These positive interventions were intentional activities. What if we compare the importance of holiday trips to an unintentional event? According to Lyubomirksy et al, (2005). unintentional activity makes up about $10 \%$ of happiness. One unintentional event may be a "medium-sized" lottery win of $£ 50.000$. Such a financial windfall increases happiness by $\sim 3 \%$ (Gardner \& Oswald. 2001, p. 7). (When dividing Gardner and Oswald's 1.09-point increase on their 36-point scale.) We should compare this to the uncontrolled effect of holiday trips, as Gardner and Oswald did not control their effect either. When doing so, we discover that winning $£ 50.000$ is less beneficial than going on a few holiday trips in a year. Additionally, the effect of the lottery win does not even have immediate gratification; it takes 2 years to take full effect. It seems that going on a holiday trip several times a year has a much bigger effect than winning $£ 50.000$ in the lottery, with the additional benefit of getting an immediate reward instead of having to wait for 2 years.

We argue that going on holiday trips is more beneficial for one's happiness in terms of intensity and duration compared to techniques such as "identifying signature strengths." "counting kindness" and "gratitude visits." especially as these studies involved people more attuned to the measurement (Otake et al., 2006) or more eager to increase their happiness (Seligman et al., 2005). Going on a holiday is just as beneficial, or even more so. than some positive intervention techniques (Seligman et al., 2005) and financial windfalls (Gardner \& Oswald, 2001). 


\subsection{Why No Effect of Other Leisure Activities?}

This study finds that out of all leisure activities, only holiday trips boost happiness. None of the other leisure activities have a significant effect on happiness. This finding partly contradicts previous findings by others (Brown, Frankel, \& Fennell, 1991: Hills \& Argyle, 1998: Suh \& Diener, 1996). The cause of this probably lies in that fact that the leisure activities all seem to fall into the category of casual leisure (Stebbins. 2007). Two other categories, project-based leisure and serious leisure (Stebbins, 2007), which may be more beneficial to one's happiness, particularly if used purposefully (Winefield, Tigermann, \& Winefield, 1992) and in congruence to their personality (Melamed, Meir, \& Samson, 1995) are not included in the data.

Additionally, the measurement level is likely to be the cause of some of the nonsignificant correlations, for instance, with watching TV. Other studies (Bruni \& Stanca, 2006, 2008: Delle Fave \& Bassi, 2003; Frey et al., 2005) found that watching TV negatively influences happiness. As most people watch TV daily, no distinction could be made between heavy users and regular viewers. This most likely explains the absence of significant correlations regarding watching TV in this study.

\subsection{Limitations}

The SOEP data have some limitations. The biggest limitation is that leisure activities are not measured every year. When measured, they are measured just once a year. Furthermore, the measurement level of the leisure activities is ordinal, and the categories are not very well chosen. This may have caused inaccurate reports as certain answers are not possible (e.g., twice a month). Future studies should incorporate more accurate methods of measuring leisure behavior. Another point of criticism is the choice of leisure activities. Some activities seem illogically combined into one variable (attend cinema, pop, jazz concerts) whereas others appear to have been excluded completely (playing computer games or visiting museums).

\subsection{Further Research}

\section{Short-Term Follow-up}

If holiday trips have a causal effect on happiness, that effect is apparently shorter than 1 year. To capture the short-lived effect, we need follow-up studies at shorter intervals, preferably every month. It is in the interest of the travel industry to fund such research.

\section{Further Analysis of SOEP Data}

Two facets of the SOEP data have not been analyzed yet. One is the total frequency and diversity of leisure activities. Do people with a wide range of leisure activities benefit more, in terms of happiness, than people with a small range of activities? The same applies to the total frequency of leisure activities; does a high frequency of leisure activities boost happiness? The other facet is the moderating effect of demographic criteria. We now know that everyone benefits, but do certain people benefit more than others from going on holiday?

\section{Optimal Tourist Lifestyle}

The interesting thing about holiday trips is that you start enjoying the experience before it actually starts. There is clearly an anticipation effect (Ryan, 1991). In that sense, it is quite a different experience from some of the aforementioned intervention techniques. 
Also. the findings presented in this study are based on current behavior. Further work needs to be done to establish whether this current behavior is optimal, in the sense that it maximizes the potential happiness boost it generates. Future research should, therefore, focus on finding out what an optimal tourist lifestyle could be. Taking short holiday trips may be particularly favorable when more evenly spread over the year. Further analysis of different tourist lifestyles is a must. Finally, future research needs to determine the exact duration of the effect of holiday trips.

\section{CONCLUSION}

Happy people report more holiday trips in the past year, probably because holiday trips boost happiness. Though the effect is short lived, it is substantial, accounting for about $2 \%$ of the variance in happiness. Holiday trips affect happiness more than other leisure activities. 
Table 4.1 Correlations between leisure activities and life satisfaction

\begin{tabular}{|c|c|c|c|c|}
\hline \multirow[t]{2}{*}{ Leisure activities } & \multicolumn{2}{|c|}{ Same-time correlations } & \multicolumn{2}{|c|}{ Over-time correlations } \\
\hline & $\mathrm{r}$ & Partial $r^{2}$ & $\mathrm{LS} \rightarrow . \mathrm{LA}$ & $\mathrm{A} \rightarrow . \mathrm{LS}$ \\
\hline Holiday trips & $.18^{* *}$ & $.14 * *$ & -.01 & .01 \\
\hline Eating and drinking & .05 & -.01 & .02 & .01 \\
\hline Visiting neighbors & .06 & .01 & .01 & -.01 \\
\hline Visiting family & .04 & .01 & .00 & .00 \\
\hline Card and board games & .03 & .02 & -.03 & -.01 \\
\hline Local politics & -.19 & -.01 & -.02 & .00 \\
\hline Volunteer work & .02 & -.01 & .03 & .00 \\
\hline Attend church & $.03 *$ & .01 & .01 & .00 \\
\hline Watch television, video & .00 & .01 & .01 & .00 \\
\hline Private computer use & .00 & -.01 & .00 & -.01 \\
\hline Private internet use & .00 & -.01 & -.01 & -.01 \\
\hline Reading & .03 & .00 & -.01 & -.02 \\
\hline Artistic, musical activities & .02 & .01 & .01 & -.02 \\
\hline Tinkering and garden work & -.02 & -.01 & .02 & .00 \\
\hline Car repairs & -.01 & -.01 & .01 & .01 \\
\hline Handicraft, home repairs & $.03 * *$ & .01 & -.02 & -.02 \\
\hline Participate in sports & .03 & .00 & -.01 & -.02 \\
\hline Attend sports events & .02 & -.01 & .01 & -.01 \\
\hline Attend cinema, concerts & .02 & .00 & .01 & -.02 \\
\hline Attend opera, theater & .01 & -.02 & .01 & .00 \\
\hline Attend cultural events & $.02 *$ & .00 & -.00 & -.03 \\
\hline
\end{tabular}


Appendix 1. Same-Time Correlations of Leisure Activities and Life Satisfaction

\begin{tabular}{|c|c|c|c|c|c|c|c|c|}
\hline & $r$ & & & & Partial & & & \\
\hline Leisure activities & 1990 & 1995 & 1998 & 2003 & 1990 & 1995 & 1998 & 2003 \\
\hline Holiday trips & $.15 * *$ & $.15 * *$ & $.18 * *$ & $.19 * *$ & $.11 * *$ & $.09 * *$ & $.19 * *$ & $.16^{* *}$ \\
\hline Eating and drinking & $.08^{* *}$ & .00 & $.04 * *$ & $.05^{* *}$ & .01 & .00 & -.03 & -.02 \\
\hline Visiting neighbors & $.07 * *$ & .02 & $.03 * *$ & $.02 * *$ & $.06^{* *}$ & .01 & -.01 & -.02 \\
\hline Visiting family & $.05 * *$ & .01 & -.01 & .00 & .03 & .00 & .01 & -.03 \\
\hline Card and board games & $.06^{* *}$ & -.01 & - & - & $.05 * *$ & -.02 & - & - \\
\hline Local politics & $.03 * *$ & .00 & -.01 & ,01 & 01 & .00 & -.02 & -.02 \\
\hline Volunteer work & $.06 * *$ & $.02 * *$ & $.02 *$ & $.02 * *$ & .01 & -.03 & .01 & -.02 \\
\hline Attend church & $.05^{* *}$ & -.02 & $.06^{* *}$ & $.04 * *$ & $.06^{* *}$ & $-.04 * *$ & .00 & .02 \\
\hline Watch television video & $.02 * *$ & .01 & $-.02 *$ & $-.01 *$ & $.04 *$ & .01 & -.01 & .01 \\
\hline Private computer use & - & - & .00 & $.03 * *$ & - & - & -.01 & -.01 \\
\hline Private internet use & - & - & - & $.03 * *$ & - & - & - & -.01 \\
\hline Reading & $.07 * *$ & -.01 & - & - & .02 & -.02 & - & - \\
\hline $\begin{array}{l}\text { Artistic, musical } \\
\text { activities }\end{array}$ & $.07 * *$ & $-.02 *$ & - & $.03 * *$ & $.05^{* *}$ & -.02 & - & .01 \\
\hline $\begin{array}{l}\text { Tinkering and garden } \\
\text { work garden work }\end{array}$ & - & - & $-.02 *$ & -.01 & - & - & -.02 & -.01 \\
\hline Car repairs & - & - & -.01 & $-.01 *$ & & - & .00 & -.02 \\
\hline $\begin{array}{l}\text { Handicraft,home } \\
\text { repairs }\end{array}$ & $.07 * *$ & $.03 * *$ & - & - & $.04 *$ & -.02 & - & - \\
\hline Participate in sports & $.12 * *$ & -.01 & .00 & $.03 * *$ & $.05 * *$ & -.02 & .00 & -.03 \\
\hline Attend sports events & $.07 * *$ & -.01 & .01 & $.02 *$ & .02 & .00 & -.01 & -.03 \\
\hline $\begin{array}{l}\text { Attend cinema, } \\
\text { concerts }\end{array}$ & $.07 * *$ & .00 & -.01 & .01 & .01 & .02 & .00 & -.02 \\
\hline Attend opera, theater & - & & .00 & $.04 * *$ & - & - & -.03 & -.01 \\
\hline Attend cultural events & $.07 * *$ & $-.02 *$ & .00 & - & .02 & -.01 & .00 & - \\
\hline
\end{tabular}


Appendix 2. Over-Time Partial Correlations of Earlier Life Satisfaction and Later Leisure Activities

\begin{tabular}{l|c|c|c|c}
\hline Leisure activities & $1989-1990$ & $1994-1995$ & $1997-$ I998 & $2002-2003$ \\
\hline Holiday trips & .02 & -.01 & .00 & -.01 \\
\hline Eating and drinking & $-.03^{*}$ & -.01 & .01 & .01 \\
\hline Visiting neighbors & -.02 & .002 & .00 & -.01 \\
\hline Visiting family & .02 & -.02 & .01 & .00 \\
\hline Card and board games & -.01 & -.02 & - & - \\
\hline Local politics & .00 & -.01 & .01 & .01 \\
\hline Volunteer work & -.01 & .01 & .01 & -.01 \\
\hline Attend church & .01 & .00 & -.01 & .00 \\
\hline Watch television, video & .00 & .01 & -.02 & .02 \\
\hline Private computer use & - & - & .00 & -.01 \\
\hline Private internet use & - & - & - & -.01 \\
\hline Reading & .00 & $-.04 * *$ & - & - \\
\hline Artistic, musical activities & -.03 & $-.05 * *$ & - & -.01 \\
\hline Tinkering and garden work & - & - & .00 & .01 \\
\hline Car repairs & - & - & .01 & .01 \\
\hline Handicraft, home repairs & -.03 & .00 & - & - \\
\hline Participate in sports & $-.05^{* *}$ & $-.03^{*}$ & .00 & -.01 \\
\hline Attend sports events & -.03 & -.01 & .00 & -.01 \\
\hline Attend cinema, concerts & -.03 & $-.04 * *$ & -.01 & .00 \\
\hline Attend opera, theater & - & - & -.01 & .00 \\
\hline Attend cultural events & -.02 & -.04 & .01 & - \\
\hline '-' No measurement: Partial correlations are controlled for age, sex, marriage, education, work, income, personality \\
and health * $p<.05: * *<.01$ & & & & \\
\hline
\end{tabular}


Appendix 3. Over-Tim e Partial Correlations of Earlier L eisure Activities and Later Life Satisfaction

\begin{tabular}{l|c|c|c|c}
\hline Leisure activities & $1990-1991$ & $1995-1996$ & $1998-1999$ & $2003-2004$ \\
\hline Holiday trips & .00 & $.04 *$ & -.01 & .00 \\
\hline Eating and drinking & .00 & $.04 *$ & .02 & .00 \\
\hline Visiting neighbors & -.01 & $.05^{*}$ & -.02 & .00 \\
\hline Visiting family & -.01 & .02 & .00 & .00 \\
\hline Card and board games & -.03 & -.03 & - & - \\
\hline Local politics & -.03 & .00 & $-.04 *$ & -.02 \\
\hline Volunteer work & -.01 & .02 & -.01 & .01 \\
\hline Attend church & -.01 & .03 & .01 & .01 \\
\hline Watch television, video & .01 & .00 & .00 & .02 \\
\hline Private computer use & - & - & .00 & .00 \\
\hline Private internet use & - & - & - & -.01 \\
\hline Reading & -.01 & .00 & - & - \\
\hline Artistic, musical activities & .00 & .03 & - & .01 \\
\hline Tinkering and garden work & - & - & .02 & .02 \\
\hline Car repairs & - & - & .03 & .01 \\
\hline Handicraft, home repairs & -.01 & $-.04 *$ & .01 & - \\
\hline Participate in sports & .00 & -.03 & .01 & .02 \\
\hline Attend sports events & -.01 & .02 & .02 & .00 \\
\hline Attend cinema, concerts & .01 & .00 & .01 & .02 \\
\hline Attend opera, theater & - & - & .00 & - \\
\hline Attend cultural events & .00 & -.01 & & - \\
\hline '-' No measurement; Partial correlations are controlled for age, sex, marriage, education, work, \\
income, personality and health $* p<.05: * *<.01$ & & & \\
\hline
\end{tabular}




\section{References}

Ateca-Amestoy, V. Serrano-del-Rosal. R.. \& Vera-Toscano, E. (2008).

The leisure experience.

The Journal of Socio-Economics, 37( 1), 64-78.

Baldwin. K., \& Tinsley, H. (1988).

An investigation of the validity of T insley and Tinsley's (1986). Theory of leisure experience. Journal of Counseling Psychology, 35(3), 263-267.

Baskersville, K., Johnson, K., Monk-Turner, E., Slone. Q., Standley, H., Stansbury, S., et al. (2000).

Reactions to random acts of kindness.

The Social Science Journal, 37(2), 293-298.

Brown, B. A., Frankel, G. B. \& Fennell, M. (1991).

Happiness through leisure: The impact of type of leisure activity, age, gender and leisure satisfaction on psychological well-being.

Journal of Applied Recreation Research. 16(4), 368-392.

Bruni, L., \& Stanca, L. (2006).

Income aspirations, television and happiness: Evidence from the world values survey.

Kyklos: internationale Zeitschrift für Sozialwissenschaften, 59(2), 209-226.

Bruni, L., \& Stanca, L. (2008).

Watching alone: Relational goods, television and happiness.

Journal of Economic Behavior \& Organization, 65(3), 506-528.

Costa. P. T., \& McCrae. R. R. (1994).

Set like plaster? Evidence for the stability of adult personality.

In T. F. H eatherton \& J. L.W einberger (Eds.). Can pe rsonality change? (pp. 21-40), Washington, DC: American Psychological Association Books.

Dehne, M., \& Schupp, J. (2007).

Persönlichkeitsmerkmale im sozio-oekonomisch en Panel (Soep) - Konzept, umsetzung und empirische Eigenschaften.

Berlin: DIW.

Delle Fave, A., \& Bassi, M. (2003).

Italian adolescents and leisure: The role of engagement and optimal experience.

New Directions for Child and Adolescent Development 99, 79-94.

Dowall, J., Bolter, C. Flett, R., \& Kammann, R, (1988).

Psychological well-being and its relationship to fitness and activity levels,

Journal of Human Movement Studies 14( 1), 39-45.

Frey, B. S., Benesch, C. \& Strutzer, A. (2005).

Does watching TV make us happy?

Zurich, Switzerland: University of Zurich, Institute for Empirical Research in Economics.

Gardner, J., \& Oswald, A. J. (2001).

Does money buy happiness? A longitudinal study using data on windfalls.

Mimeo: Warwick University. 
Gilbert, D., \& Abdullah, J. (2002).

A study on the impact of the expectation of a holiday on an individual's sense of well-being. Journal of Vacation Marketing, 8(4), 352-361.

Gilbert, D., \& Abdullah, J. (2004).

Holidaytaking and the sense of well-being.

Annals of Tourism Research, 31(1), 103-121.

Gustavsson, J. P., W einryb, R. M., Göranss on, S., Pedersen, N. L., \& Åsberg, M. (1997).

Stability and predictive ability of personality traits across 9 years.

Personality and Individual Differences, 22(6), 783-792.

Hampson, S. E., \& Goldberg, L. R. (2006).

A first large cohort study of personality trait st ability over the 40 years between elementary school and midlife.

Journal of Personality and Social Psychology, 91(4), 763-779.

Haworth, J. T. (1997).

Work, leisure and well-being.

London and New York: Routledge.

Hills, P., \& Argyle, M. (1998).

Positive moods derived from leisure and their relationshi $p$ to happiness and personality.

Personality and Individual Differences, 25(3), 523-535.

Laukka, P. (2007).

Uses of music and psychological well-being among the elderly.

Journal of Happiness Studies, 8(2), 215-241.

Lloyd, K., \& Auld, C. J. (2002).

The role of leisure in determining quality of life: Issues of Content and measurement.

Social Indicators Research, 57( 1), 43-71.

Lyubomirksy, S., Sheldon, K. M., \& Schkade, D. (2005).

Pursuing happiness: The architecture of sustainable change.

Review of General Psychology, 9(2), 111-131.

McCrae, R. R. \& Costa, P. T. (2003).

Personality in adulthood: A five-factor theory perspective.

New York: Guilford.

McCrae, R. R., \& John, O. P. (1992).

An introduction to the live-factor model and its applications.

Journal of Personality, 60(2), 175-215.

Melamed, S., Meir, E. I., \& Samson, A. (1995).

The benefits of personality-leisure congruence:

Evidence and implications.

Journal of Leisure Research, 27( 1), 25-40.

Milman, A. (1998).

The Impact of tourism and travel experience on senior travelers' psychological well-being, Journal of Travel Research, (2), 166-170. 
Nawijn, J. (2007, April 23-25).

Happiness and long haul leisure trips.,

Paper presented al the tourism, mobility and technology, Nice, France.

Neal, J. D. (2000).

The effects of different aspects of tourism services on travelers' quality of life: Model validation, refinement, and extension.

Blacksburg, Virginia: Virginia Polytechnic Institute And Slate University.

Neal, J. D., \& Sirgy, M. J. (2004).

Measuring the effect of tourism services on travelers' quality of life: Further validation.

Social Indicators Research, 69(3), 243.

Neal, J. D., Sirgy, M. J., \& Uysal, M. (1999).

The role of satisfaction with leisure travel-tourism services and experience in satisfaction with leisure life and overall life.

Journal of Business Research, 44(1), 153-164.

Otake, K., Shimai, S., Tanaka-Matsumi, J., Otsui, K., \& Fredrickson, B. L. (2006).

Happy people become happier through kindness: A counting kindness intervention, Journal of Happiness Studies, 7(3), 361-375.

Ryan, C. (1991).

Recreational tourism: A Social science approach.

London: Routledge.

Seligman, M., Steen, T.A., Park, N., \& Peterson, C. (2005)

Positive psychology progress.

The American Psychologist, 60(5), 410-421.

Sirgy, M. J., \& Cornwell, T. (2001).

Further validation of the Sirgy et al.'s Measure of Community Quality of Life.

Social Indicators Research, 56(2), 125-143.

Sirgy, M. J., Rahtz, D., Cicic, M., \& Underwood, M. (2000).

A method for assessing residents' satisfaction $w$ ith community-based services: A quality-of-life perspective.

Social Indicators Research, 49 (3), 279-316.

Spiers, A., \& Walker, G. J. (2009).

The effects of ethnicity and leisure satisfaction on happiness, peacefulness, and quality of life . Leisure Sciences., 31(1), 84-99.

Slebbins, R. A. (2007).

Serious leisure: A perspective for our time.

New Brunswick and London: Transaction Publishers.

Strauss-Blasche, G., Ekmekcioglu, C. \& Marktl, W. (2002).

Moderating effects of vacation on reactions to work and domestic stress.

Leisure Sciences, 24 (2). 237-249.

Suh, E. M., \& Diener, E. (1996).

Events and subjective well-being: Only recent events matter.

Journal of Personality and Social Psychology, 70(5), 1091-1102. 
Terraciano, A., Costa, P. T., \& McCrae, R. R. (2006).

Personality plasticity after age 30.

Personality and Social Psychology Bulletin, 32( 8), 999-1009.

Van Praag, B. M. S., \& Ferrer-i-Carbonell, A. (2004).

Happiness quantified: A satisfaction calculus approach.

Oxford: Oxford University Press.

Van Praag, B. M. S., Frijters, P., \& Ferrer-i-Carbonell, A. (2003).

The anatomy of subjective well-being.

Journal of Economic Behavior \& Organization, 51(1), 29-19.

Veenhoven, R. (1984).

Conditions of happiness.

Dordrecht, Netherlands: Reidel.

Veenhoven, R. (2008).

World database of happiness, Correlational findings:

http://worlddatabaseofhappiness.eur.nl.

Wankel, L., \& Berger, B. (1990).

The psychological and social benefits of sport and physical activity.

Journal of Leisure Research, 22(2), 167-182.

Winefield, A. H., Tigermann, M., \& Winefield, H. R. (1992).

Spare time use and psychological well-being in employed and unemployed young people. Journal of Occupational and Organizational Psychology, 65( 1), 307-313. 